\title{
Unpacking the Public Private Partnership Revival
}

\author{
Kate Bayliss, SOAS University of London (kb6@soas.ac.uk) \\ Elisa Van Waeyenberge, SOAS University of London (ew23@soas.ac.uk)
}

\begin{abstract}
This paper examines the recent resurgence of interest in public-private partnerships (PPPs) to provide infrastructure in developing countries. First, the paper demonstrates that there has been a revival of support for private sector participation in infrastructure. Second, the paper argues that this revival differs from earlier attempts to increase the involvement of the private sector in public service provision in a number of respects. In particular, the current support for PPPs is related to an increased availability of global financial capital. Third, the paper considers the implications of this distinct feature of the revival for development.
\end{abstract}

\section{Introduction}

There has been a strong resurgence of interest in PPPs for infrastructure in recent years. ${ }^{i}$ In the developing world, this resurgence has been led by the World Bank but has also received strong support from other multilateral development institutions, bi-lateral donors, national governments and various other organizations. Indeed, a number of global initiatives have recently been established to promote the adoption of PPPs. These range from platforms seeking to pair investors with investment opportunities in the developing world 
This is the accepted version of an article accepted for publication in Journal of Development Studies published online 27 March 2017 Taylor \& Francis: http://dx.doi.org/10.1080/00220388.2017.1303671

Accepted version downloaded from SOAS Research Online: https://eprints.soas.ac.uk/23702

to on-line training in support of PPP adoption. Across these, PPPs are presented as essential to address large infrastructure deficits in developing countries.

PPPs take various forms. ${ }^{\text {ii }}$ They differ from traditional public procurement through the nature of the contract between the public and private sector, and their aim is to shift risk and management responsibility to the private sector through output rather than input specifications regarding infrastructure service delivery (IEG, 2014, p. vii). They usually take the form of a concession-type contract with variations in the requirements from the private partner in the configurations of Design, Finance, Build, Operate, Maintain and Transfer of the infrastructure asset. The exact nature of the partnership of PPPs varies but, across the range, governments remain ultimately accountable for services provided. Funding for PPPs is derived either from the state, from users, or through a combination of both.

For supporters, PPPs bring efficiency, innovation and finance. At the same time, PPPs offer returns to investors and appear as a win-win resolution of the gap between a country's infrastructure needs and the public funds available to finance these. Yet, PPPs remain a highly contested vehicle for infrastructure financing and delivery. Critics have pointed to their high costs, the long-term and rigid nature of contracts, the difficulty in finding sufficient appetite on behalf of private investors, and varying assessments of their performance in terms of efficiency, risk transfer and social impact (UNDESA, 2016; Boardman et al., 2016; Trebilcock \& Rosenstock, 2015; Hall, 2014; Romero, 2015; Torchia et al., 2015; 
This is the accepted version of an article accepted for publication in Journal of Development Studies published online 27 March 2017 Taylor \& Francis: http://dx.doi.org/10.1080/00220388.2017.1303671

Accepted version downloaded from SOAS Research Online: https://eprints.soas.ac.uk/23702

Roehrich et al., 2015). The evidence seems to indicate that they need to be treated with caution, both on a project-specific basis and as an increasingly embedded route to infrastructure or public service provision.

Against this backdrop, this paper critically explores the recent resurgence of interest in PPPs. It does so by addressing two core questions: first, what are the distinct features of the recent revival of PPP promotion and, second, what issues do these raise in the context of development policy? As we engage with these issues, we understand PPPs as another manifestation of a push for the increased involvement of the private sector in public service provision, which came to the fore in development policy initially with the drive for privatisation that dates back to the 1980s. And, while aware of the differences between 'outright' privatisation or 'divestiture' and a PPP arrangement, not in the least in the extent and nature of the involvement and relations between private and public sectors, our interest relates to their shared agenda of extending the reach of the private sector in the provision of essential services which would previously have been understood as the preserve of the public sector (see also O'Neill et al., 2009). We hence use privatisation as a broad (analytical) category corresponding to a range of operational (concrete) manifestations along a spectrum of contractual arrangements.

The paper then argues that the current efforts to promote PPPs differ from earlier initiatives that sought to promote private sector involvement in infrastructure in their reflection of a specific set of underlying imperatives. While 
This is the accepted version of an article accepted for publication in Journal of Development Studies published online 27 March 2017 Taylor \& Francis: http://dx.doi.org/10.1080/00220388.2017.1303671

Accepted version downloaded from SOAS Research Online: https://eprints.soas.ac.uk/23702

earlier drives for privatisation in donor advocacy formally highlighted the potential efficiency gains deriving from increased private sector involvement in public service provision, the more recent wave of PPP advocacy is anchored almost entirely in arguments seeking to match a glut in global savings with the need to upscale public service provision in developing countries. This has created an increasingly financialised approach to infrastructure, as policy is framed in terms of investment opportunities for financial investors and institutional arrangements bearing on infrastructure provision are reconfigured to facilitate their entry into the sector.

The paper highlights the hazards of such a framing and situates these in the context of well-established critiques of PPPs in development studies. Through its critical engagement with the distinct features of the current PPP advocacy revival, the paper offers a complementary contribution to Trebilcock \& Rosenstock (2015), which drew out lessons from recent experiences with PPPs for the developing world without exploring further the implications that derive specifically from the particular constellation of the PPP advocacy revival.

The paper proceeds as follows. Section two documents the revival of PPP promotion in donor discourse and sets this in a historical perspective. Section three analyses the nature of the revival and highlights that, unlike earlier privatisation promotion efforts, the current revival is underpinned by imperatives related to the availability of global financial flows. Section four 
This is the accepted version of an article accepted for publication in Journal of Development Studies published online 27 March 2017 Taylor \& Francis: http://dx.doi.org/10.1080/00220388.2017.1303671

Accepted version downloaded from SOAS Research Online: https://eprints.soas.ac.uk/23702

considers the implications of this distinct feature of the PPP revival for

infrastructure and development policy. Section five concludes.

\section{The Global PPP Revival}

The involvement of the private sector in public service provision has been promoted in development discourses and practices in various guises since the early 1980s. This was most emblematic with the initial shift towards privatisation that can be traced to the World Bank's (1981) Berg Report. Yet, despite strong support from donors, most notably the World Bank, privatisation in general failed to bring about the transitions that had been expected.

Privatisation seemed more difficult to implement than had been anticipated and criticism of its practice grew rapidly. Critical arguments included that it was competition rather than ownership changes that generated productivity gains that reach end users (IMF, 2004) and this effect tended to be limited as the markets in which privatised utilities operate are less contestable due to large sunk costs. In response it was argued that competition without hard budget constraints would not improve efficiency (Shirley \& Walsh, 2000 for a review of this literature). Furthermore, private firms failed disproportionately to invest in areas of greatest need and the investment that was forthcoming tended to be in the form of take-over of existing facilities adding little to capacity (see Bayliss \& Fine, 2008). 
This is the accepted version of an article accepted for publication in Journal of Development Studies published online 27 March 2017 Taylor \& Francis: http://dx.doi.org/10.1080/00220388.2017.1303671

Accepted version downloaded from SOAS Research Online: https://eprints.soas.ac.uk/23702

Privatisation appeared to go into decline during the 2000s both in terms of development discourse and policies in practice (see World Bank, 1997; Kessides, 2004). ${ }^{\mathrm{iii}}$ And while donor discourse promoting private sector involvement in infrastructure does not necessarily translate directly into trends in private participation in infrastructure, Figure 1 gives a sense of how the phenomenon gained prevalence during most of the 1990s before slowing down at the turn of the millennium (mainly as a result of the Asian financial crisis). The figure also shows how private participation in infrastructure picked up rapidly from the mid-2000s onwards. The decline since 2012 is due to lower investments in Brazil, China and India (World Bank, 2016). In education and health, while the involvement of the non-state actors is not new, there has been a notable increase in the adoption of PPPs as a formal policy model, reconfiguring relations between the state and private providers (Languille, 2016).

Figure 1: Trends in private participation in infrastructure, iv $1992-2015$, number of projects (RHS) and investment commitments (LHS) 
This is the accepted version of an article accepted for publication in Journal of Development Studies published online 27 March 2017 Taylor \& Francis: http://dx.doi.org/10.1080/00220388.2017.1303671

Accepted version downloaded from SOAS Research Online: https://eprints.soas.ac.uk/23702

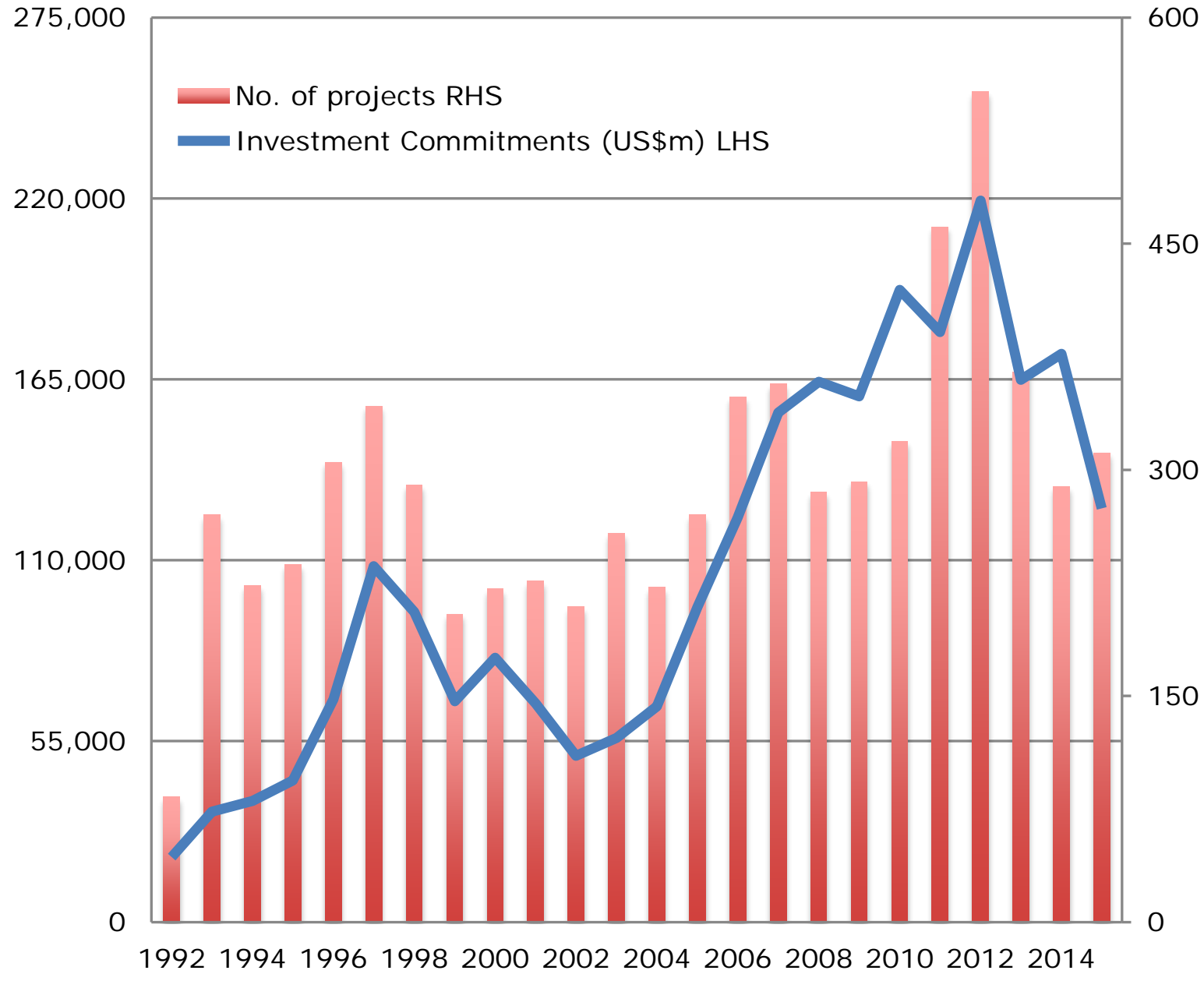

Source: World Bank Private Participation in Infrastructure (PPI) database

The Global Financial Crisis (GFC), however, had potentially damaging implications for the prospects of the expansion of the private sector in infrastructure in the developing world reducing the scope for bond issuance and bank lending to private infrastructure projects (see below). Donors responded by increasing support for private investors to stabilise existing projects and continue the flow of new investments, for example, with the Infrastructure Crisis Facility (World Bank, 2010). 
This is the accepted version of an article accepted for publication in Journal of Development Studies published online 27 March 2017 Taylor \& Francis: http://dx.doi.org/10.1080/00220388.2017.1303671

Accepted version downloaded from SOAS Research Online: https://eprints.soas.ac.uk/23702

More recently, a number of donor-led programmes to support PPPs have emerged and development policy is increasingly oriented around raising funds from the private sector. This was reflected, for instance, in the role assigned to PPPs in the outcome document of the Financing for Development 3 Summit (Addis Ababa, July 2015) which sets out the financing framework for the sustainable development goals (SDGs) endorsed by the United Nations in September 2015 (www.un.org/ffd3). The Paris Climate Change Agreement of December 2015 also strongly relies on private financing to implement its agenda (World Bank, 2015).

Donor initiatives increasingly seek to use donor and government funds to leverage private finance for infrastructure. And, while the principles behind leveraging have been around for some time, there has been a sharp increase in interest in the donor community recently (see UKAN, 2015; Eurodad, 2013, p. 8; World Bank/IMF, 2015; Ferrer \& Behrens, 2011; Griffiths, 2012). ${ }^{\text {v Notable are }}$ guarantees that are intended to make projects less risky and therefore more attractive to investors (Miyamoto \& Chiofalo, 2015). Donors further provide debt and equity finance for PPPs. Such measures come under the heading of blended finance, which is intended to 'catalyse' private capital by reducing risks or increasing returns (see Martin, 2015). ${ }^{\mathrm{vi}}$

For the World Bank Group, PPP programmes are part of its effort 'to spur growth and fight poverty' (IEG, 2014, p. 2) and its support for PPPs has increased more than threefold from US $\$ 0.9$ billion to US $\$ 2.0$ billion over the last decade 
This is the accepted version of an article accepted for publication in Journal of Development Studies published online 27 March 2017 Taylor \& Francis: http://dx.doi.org/10.1080/00220388.2017.1303671

Accepted version downloaded from SOAS Research Online: https://eprints.soas.ac.uk/23702

(Romero, 2015, p. 16). PPPs are seen as having 'the potential to close the infrastructure gap by leveraging scarce public funding and introducing private sector technology and innovation to provide better quality public services through improved operational efficiency' (p. 5). This is intended to contribute to growth and, through 'trickle down', to poverty reduction (see IEG, 2014, p. 7). In addition 'through leveraging infrastructure investments through private sector funds, PPPs can free resources that the government would have used to fund its public investment program and can now use for other priorities' (IEG, 2014, p. 7 emphasis added).

Regional development banks have also become strong supporters of PPPs. In 2014, the Asian Development Bank (AsDB) established an Office of PublicPrivate Partnership (OPPP) to enhance the role of the AsDB in supporting governments to increase private investment. According to the AsDB's Operational Plan, its practices need to be 'redesigned to make fully privatefinanced projects, followed by PPPs the preferred option before resorting to public (sovereign)-financed projects' (AsDB 2012, p. vi, emphasis added). For the African Development Bank 'PPPs have emerged over the last decade as one of the best ways to foster development, fuelled by insufficient investment, growing pressures on government budgets and a general concern about service provision by state enterprises and agencies'. vii

In addition to their separate programmes of support, multilateral development institutions have collaborated in support of PPP initiatives in recent years. A web 
This is the accepted version of an article accepted for publication in Journal of Development Studies published online 27 March 2017 Taylor \& Francis: http://dx.doi.org/10.1080/00220388.2017.1303671

Accepted version downloaded from SOAS Research Online: https://eprints.soas.ac.uk/23702

resource called the PPP Knowledge Lab was set up in 2015

(https://pppknowledgelab.org) to collate research on PPPs, and the World Bank’s Public Private Partnership in Infrastructure Resource Centre which provides information on legal and institutional aspects of PPP in developing countries received an improved online home in 2014

(https://ppp.worldbank.org/public-private-partnership). In addition, in January 2015, the PPPIRC launched what they describe as a "Massive Open Online Course" on how to make PPPs deliver better services.

Donor agencies and governments have also coordinated to create more substantial support for PPPs through project facilitation platforms. These aim to connect global financial flows with infrastructure needs in developing countries (and developed countries in some cases). Such platforms include the G20 Global Infrastructure Hub which was created in 2014, the AfDB's Africa 50 Infrastructure Fund set up in 2015, viii the World Economic Forum/OECD Sustainable Development Investment Partnership launched at the Third International Conference on Financing Development in 2015, and the World Bank's Global Infrastructure Facility created in 2014 (OECD, 2015, p. 31; Schmidt-Traub \& Sachs, 2015; Miyamoto \& Chiofalo, 2015). These platforms often promote the 'pooling' of PPPs, where public entities are advised not to engage in isolated PPPs but to undertake a number of projects simultaneously through a portfolio approach (World Bank/IMF, 2015; United Nations, 2014, p. 37; Alexander, 2015). 
This is the accepted version of an article accepted for publication in Journal of Development Studies published online 27 March 2017 Taylor \& Francis: http://dx.doi.org/10.1080/00220388.2017.1303671

Accepted version downloaded from SOAS Research Online: https://eprints.soas.ac.uk/23702

At the country level, numerous governments have recently established PPP

Units, largely with donor support. Following the practice in OECD countries (see OECD, 2010; EPEC, 2014), these units propose legislation to promote PPPs and draw up lists of bankable projects across sectors (Dutz et al., 2006). ix For example, Kenya set up a PPP Unit under Section 8 of the Public Private Partnership Act (2013) as a specialized unit within the Treasury to promote and to oversee the Kenya's PPP programme (pppunit.go.ke). The Unit has published a National Priority list of 59 PPP projects covering a range of sectors from health to housing to water.

While support for the involvement of the private sector in the provision of infrastructure in developing countries has fluctuated since the 1980s, development policy in the past few years has become strongly focused on PPPs as a way to overcome infrastructure deficits and to increase access to essential services. The next section explores the distinct features of the current revival of promotion of private sector involvement in infrastructure. It highlights how recent advocacy efforts have been characterised by an attempt to link deficiencies in public service provision in developing countries to a glut of global savings. This is followed by a subsequent section which considers the implications thereof.

\section{Unpacking the PPP Revival}


This is the accepted version of an article accepted for publication in Journal of Development Studies published online 27 March 2017 Taylor \& Francis: http://dx.doi.org/10.1080/00220388.2017.1303671

Accepted version downloaded from SOAS Research Online: https://eprints.soas.ac.uk/23702

This section explores three key features that underpin the current revival of PPP advocacy. First, unlike the privatisation of the 1990s, PPP policy is now driven far more by the availability of global finance than by the previously perceived potential for efficiency gains through privatisation. Second, this has led to the institutional restructuring and reconfiguration of infrastructure with the aim of facilitating the entry of financial investors. Third, this shift has been supported by a policy framework that is strongly oriented towards private sector involvement rather than alternatives based on public sector provision.

\subsection{Finance-driven PPPs}

The PPP advocacy revival documented above captures a response to a set of contradictory tendencies bearing on the PPP financing model generated by the Global Financial Crisis (GFC). Indeed, in the aftermath of the GFC, the traditional debt- financed model for PPPs was hit through substantial increases in the cost of borrowing for infrastructure financing with possible negative implications for the 'value for money' case proposed by PPP advocates.

This was the result of two specific financial consequences of the crisis. On the one hand, new regulatory requirements (Basel III), which aim to strengthen the banks' balance sheets, require that banks hold more capital for longer-term loan. Banks have responded through credit retrenchment for infrastructure financing (OECD, 2014a). On the other hand, previously, commercial bond financing was largely insured by the large US monoline insurers. Monolines insured the project 
This is the accepted version of an article accepted for publication in Journal of Development Studies published online 27 March 2017 Taylor \& Francis: http://dx.doi.org/10.1080/00220388.2017.1303671

Accepted version downloaded from SOAS Research Online: https://eprints.soas.ac.uk/23702

risk and guaranteed repayments to bondholders in return for a fee and therefore reduced overall financing costs. However, through their exposure to the US subprime mortgage market, many suffered credit rating downgrades and investors ceased investing in Monoline-wrapped project bonds. These effects of the GFC served to increase the cost of traditional debt-based PPP infrastructure finance relative to public borrowing, undermining the case for PPPs.

A quote from Hamilton (2009, p. 12), Head of the Cooperation and Partnership Section of the United Nations Economic Commission for Europe (UNECE) neatly captures this tension: ${ }^{\mathrm{x}}$

the financial crisis has resulted in credit problems for private companies, but less for governments. Banks and investors continue to lend money to governments and the costs of that has actually been falling in some countries. What is more important is that governments can borrow at an interest rate much lower than the private sector could obtain. The gap in the financing cost between the public sector and the private sector provides one argument for people advocating the withdrawal of the participation of the private sector in public service financing. The general belief that the private sector would ... manage risks much better than the public sector has been undermined by the financial crisis.

However, the response has been to reorient the financing model of PPPs to capture the possibilities offered through the search by institutional financial 
This is the accepted version of an article accepted for publication in Journal of Development Studies published online 27 March 2017 Taylor \& Francis: http://dx.doi.org/10.1080/00220388.2017.1303671

Accepted version downloaded from SOAS Research Online: https://eprints.soas.ac.uk/23702

investors for long-term and stable returns rather than supporting a return to public finance. This reorientation corresponds to financial investors' search for investment opportunities that offer stable, long-term (and inflation-linked) yields, in particular after having suffered substantial losses through exposure in the global financial crisis (Hebb \& Sharma, 2014; OECD, 2014a; Torrance, 2009; DAWM, 2015). PPP schemes offer such returns, with 'relatively low credit risk (if not overleveraged), with high observed and projected recovery rates in case of default' (Standard \& Poor's, 2013, p. 4). The massive liquidity injections by Central Banks through quantitative easing which have compressed yields of debt capital market instruments have also provoked a search for yields by institutional investors in instruments such as those offered through 'infrastructure as an asset class'.

Infrastructure assets typically provide higher yields than government bonds (see DAWM, 2015; OECD, 2014a, p. 6; WEF, 2015, p. 6) and quantitative easing, rather than stimulating domestic expansion as originally intended, facilitates the expansion of financial investment into infrastructure worldwide. Arezki et al. (2016, p. 6) note how '[l]ong-term investors are well placed to invest in more long-term global infrastructure assets which match their long-term horizon ... In the current low-yield environment, in particular, harvesting the illiquidity premium has become increasingly important for many long-term investors'. Alexander (2015) highlights how policy-makers see 'long-term institutional investors, such as pension funds and sovereign wealth funds, as the key to bridging the [infrastructure] gap'. ${ }^{x i}$ For Inderst \& Stewart (2014, p. i), 
This is the accepted version of an article accepted for publication in Journal of Development Studies published online 27 March 2017 Taylor \& Francis: http://dx.doi.org/10.1080/00220388.2017.1303671

Accepted version downloaded from SOAS Research Online: https://eprints.soas.ac.uk/23702

'[c]hallenges of financing infrastructure projects come from stretched

government finances and restrictions on global bank lending. Hence, much attention has been focused on the potential for institutional investors as a growing potential source of financing'.

The enthusiasm for PPPs today then relates, in part, to a large pool of global financial resources looking for investment opportunities. A report by McKinsey (2016), for example, states that current global annual investment in infrastructure falls short by nearly US\$1 trillion a year to support expected growth rates. This gap could partly be plugged by assets belonging to institutional investors and banks. Similarly, Arezki et al. (2016, p. 5) point to the enormous size of the global wealth in the hands of pension funds, insurance companies, mutual funds and sovereign wealth funds, that could be channelled to financing infrastructure.

Donor initiatives to promote PPPs aim to tap into this supply of funds. The Global Infrastructure Facility (GIF) for example, 'represents about $\$ 12$ trillion in assets under management, seeking diversification into productive investments with risk-reflective returns' according to its website. xii Furthermore, '[b]y building a global pipeline of sustainable infrastructure investment projects, structured to meet both the needs of service users and the investment appetites of such investors, the GIF has the potential to unlock billions of dollars for infrastructure in the developing world.' 
This is the accepted version of an article accepted for publication in Journal of Development Studies published online 27 March 2017 Taylor \& Francis: http://dx.doi.org/10.1080/00220388.2017.1303671

Accepted version downloaded from SOAS Research Online: https://eprints.soas.ac.uk/23702

As such, the PPP advocacy revival and the attempted reconfiguration of its

financing model is driven to a significant extent by the existence of a large pool of funds looking for stable investment outlets. For supporters, this creates a winwin opportunity with a global pool of finance available to invest in regions and sectors where finance is sorely needed. However, such a matching is far from straightforward and it raises a set of fundamental issues. How, for instance, are the higher yields offered by infrastructure assets as compared to government bonds generated and what are the distributional implications of this differential cost to the taxpayer or user? To whose benefit and at whose expense is infrastructure turned into assets with such higher returns? Further, how are we to appraise a model that turns infrastructure into assets to deliver yields to private investors, against the backdrop of historic levels of income inequality and the persistent deficit in poor people's access to basic services across large parts of the developing world? Some of these issues are further explored below.

\subsection{Infrastructure as an Asset Class}

With finance to the fore, infrastructure policy is increasingly framed around creating projects that will be of interest to investors. The areas of provision that are potentially able to generate private revenue are separated to make them more easily accessible to investors. This is demonstrated in the lists of pipeline projects drawn up by country PPP units which list elements of services that can be hived off and packaged as investor assets. In the water sector, for example, water utilities attracted little interest from private investors in the 1990s and 
This is the accepted version of an article accepted for publication in Journal of Development Studies published online 27 March 2017 Taylor \& Francis: http://dx.doi.org/10.1080/00220388.2017.1303671

Accepted version downloaded from SOAS Research Online: https://eprints.soas.ac.uk/23702

2000s. The PPP pipelines, however, now separate water treatment plants from the rest of the utility. An investor can produce bulk water and can sell this to the water utility under a fixed price contract for a specified minimum level of demand for decades. This minimises investor risk and makes a project 'bankable'.

The result is a portfolio of infrastructure investment projects with the most lucrative allocated to private finance. The way in which governmental and intergovernmental agencies offer support for the expansion of private finance in infrastructure is also shaped by emerging configurations in the financial markets. The shift towards attracting institutional investors' money into PPP assets, for instance, is reflected in the promotion of a 'pooled' approach to PPPs as one of the distinguishing features of the current revival, with the promotion of such 'pooling' or 'wholesaling' of PPPs corresponding to the financing preferences of the investors that are being targeted through the revival. Pooling of smaller infrastructure projects allows project revenues and risks to be packaged together and to attract 'major investors who might otherwise see the individual projects as too small to bother with.'xiii For Arezki et al. (2016, p. 12) 'new institutional innovations are required in the current era that can channel the vast pools of long-term savings parked in low-yielding assets towards higher-return long-term infrastructure assets'. So, while large shares of investments by institutional investors have traditionally targeted government bonds or other fixed income securities (Çelik \& Isaksson, 2013), infrastructure as asset offers prospects for higher yields that are being actively explored. 
This is the accepted version of an article accepted for publication in Journal of Development Studies published online 27 March 2017 Taylor \& Francis: http://dx.doi.org/10.1080/00220388.2017.1303671

Accepted version downloaded from SOAS Research Online: https://eprints.soas.ac.uk/23702

Promoting finance-driven infrastructure gives rise to shifting roles for the state and for investors as well as altering relations between them. Recent revival initiatives represent attempts to capitalise on non-traditional investors' interest in infrastructure financing, and the state's role is to provide appropriate incentives for such investors. For the OECD (2014a, p. 38): 'The role of the public sector in subsidizing and/or incentivising private participation is important particularly in markets where the role of public entities is still dominant and the PPP model is still underdeveloped or at very early stage of use'. For the World Bank (2013a, p.25) 'scaling up infrastructure investments, therefore, can only happen if governments ensure that incentives, pricing and regulations are aligned'.

Also in the private sector new structures and institutions have emerged in response to the promotion of infrastructure as an asset class. A number of banks have established investment funds focusing wholly or in part on infrastructure (Ashton et al., 2012). These link developed and developing country households with institutional and individual investors via chains of financial intermediaries. In addition private financial investors are working closely with donors and policy makers. For example, the World Bank's IFC is investing US\$100m in the private equity fund set up by Australian investment bank Macquarie, known as Macquarie Africa Infrastructure Investment Fund. Similarly, the Global Infrastructure Facility brings together partners that include institutional investors, commercial banks and development finance institutions to collaborate 
This is the accepted version of an article accepted for publication in Journal of Development Studies published online 27 March 2017 Taylor \& Francis: http://dx.doi.org/10.1080/00220388.2017.1303671

Accepted version downloaded from SOAS Research Online: https://eprints.soas.ac.uk/23702

to ensure that 'well-structured and bankable infrastructure projects are brought to market in a way that sustainably meet the needs of governments and service users'. xiv Thus investors are helping governments to design infrastructure in a way that suits the needs of investors (or is 'bankable'). This is not to say that projects will not achieve stated objectives but merely that the ability of infrastructure to generate attractive financial returns will be central to the project structure, possibly in contrast to traditional government procurement which may have greater scope to pursue social objectives.

\subsection{Ideological Bias}

Privatisation and the PPP revival in infrastructure have long been supported by a strong ideological bias against state provision. In developed and developing countries the state is often portrayed as having a history of cost overruns, white elephants and unfinished infrastructure projects. Soft budget constraints in the public sector are associated with poor decision-making. Most recently, Arezki et al. (2016, p. 10), for instance, associate the state with 'corruption, excess bureaucracy and general incompetence'.

The presumption persists that the private sector, despite its limitations, remains better than alternatives offered through the public sector, even though the analytical foundations to such a position remain unclear. Yet the evidence on efficiency improvements from introducing the private sector is far from compelling. Trebilcock \& Rosenstock (2015) provide a comprehensive review. 
This is the accepted version of an article accepted for publication in Journal of Development Studies published online 27 March 2017 Taylor \& Francis: http://dx.doi.org/10.1080/00220388.2017.1303671

Accepted version downloaded from SOAS Research Online: https://eprints.soas.ac.uk/23702

They show that, while some studies indicate that PPPs are more efficient than traditional procurement, the evidence is mixed with productivity gains often linked to cuts in employment. There are other extensive assessments that have been critical of the efficiency impact of PPPs (see Shaoul et al., 2012;

Alexandersson \& Hulten, 2009; Perkins, 2013; Funke et al., 2013; Hall, 2014;

Hildyard, 2012; Vining \& Boardman, 2008; Jupe, 2009). This includes a report by the IMF (2015, p. 11) which offers an ambiguous assessment and the World Bank's own recent assessment of twenty-two Bank-promoted PPPs in nine countries which finds that indicators for efficiency are mixed (IEG, 2014, p. 72). For two IMF researchers, most recently: 'the efficiency gains from PPPs could be offset by the typically higher borrowing costs faced by the private sector, as well as the significantly higher transaction costs of PPPs. Empirical analyses suggest that whether or not PPPs have achieved their efficiency objectives in practice remains an open question' (Jin \& Rial, 2016, p. 22).

Further, while private providers have incentives to lower costs and increase revenue, there is no reason why that should have wider societal benefits in the absence of competition. Perkins $(2013$, p. 8) argues that innovation in the design and construction techniques of PPPs can sometimes achieve major cost savings. However, the author cautions that the scope for such savings can be small in part because of the contractual process, which requires contracts to be tightly specified at the start (p. 32). 
This is the accepted version of an article accepted for publication in Journal of Development Studies published online 27 March 2017 Taylor \& Francis: http://dx.doi.org/10.1080/00220388.2017.1303671

Accepted version downloaded from SOAS Research Online: https://eprints.soas.ac.uk/23702

Boardman et al. (2016, p. ii, emphasis added) highlight that PPPs do not do away with the problems of public procurement but make them more difficult to discern:

[A]ll those risks that are supposedly transferred to private players are never truly transferred: The government is always the residual risk holder should the consortium somehow fail. From a policy standpoint, the measure of whether PPPs are worthwhile should be based not on whether they come in on time or on budget, but whether they increase social value relative to a PSA [Public Sector Alternative]. There is, currently, no convincing evidence that they do.

Yet policy making is often imbued with an anti-state bias and the presumption of poor state performance persists. This is evidenced in the notion of the approach to the financing gap itself. While undoubtedly developing countries' infrastructure sectors need extensive investment, attempting to fill the gap with private investment is not necessarily an obvious policy response. The calculation of a financing gap could lead to calls to raise tax revenue, to curb capital flight, to raise aid flows, to improve fiscal management or to raise public bonds. Policy advocacy instead is dominated by measures to attract global private capital.

Consider a briefing paper by the ratings agency Standard \& Poor's (2014), which discusses a set of government spending scenarios and their implications for the annual infrastructure financing gap. The briefing's financing gap emerges on the 
This is the accepted version of an article accepted for publication in Journal of Development Studies published online 27 March 2017 Taylor \& Francis: http://dx.doi.org/10.1080/00220388.2017.1303671

Accepted version downloaded from SOAS Research Online: https://eprints.soas.ac.uk/23702

basis of an estimated current average of public infrastructure investment worldwide of three per cent of GDP. The briefing adds that this represents a historically low level of public spending on infrastructure (see also IMF, 2015). If governments were, on average, to increase their spending by a half percentage point to 3.5 per cent of GDP, 'the funding requirement through 2030 could be fully met through public funding' (Standard \& Poor's, 2014, p. 7). Stated differently, the financing gap would disappear. Ultimately, the ability of a government to finance public investment depends on its fiscal space, this is its ability to raise revenue and rely on debt instruments or external grants (see Weeks \& McKinley, 2007; Heller, 2005). PPP advocacy efforts reflect a presumption that governments and international organisations cannot mobilise the necessary resources to finance the up-scaling of infrastructure worldwide.

The ideological bias is also observable in the decision-making processes bearing on PPP adoption. For example, it is widely stated that PPPs should only be introduced if they provide value for money (VfM). The World Bank's Independent Evaluation Group (IEG, 2014, p. 22) explicitly argues that the decision of public procurement versus PPPs 'needs to be made on the basis of a comprehensive value for money assessment'. But it is far from clear what this means let alone how it should be carried out. The VfM assessment process is based on a raft of assumptions, including those regarding the higher cost of a public sector comparator (PSC). These calculations are open to contestation and have been found to incorporate prior commitments to PPP investments (see Shaoul et al., 2012, p. 30; Engel et al., 2010; Tsamboulas et al., 2013; Boardman \& 
This is the accepted version of an article accepted for publication in Journal of Development Studies published online 27 March 2017 Taylor \& Francis: http://dx.doi.org/10.1080/00220388.2017.1303671

Accepted version downloaded from SOAS Research Online: https://eprints.soas.ac.uk/23702

Hellowell, 2016). Tsamboulas et al. (2013, p. 123) add that various socioeconomic and qualitative factors, which cannot be monetized are excluded from VfM assessments. These factors may, however, strengthen arguments in favour of public procurement when they capture wider social impacts or environmental and safety concerns which are not easily accounted for in cost-benefit type analysis.

The World Bank's IEG (2014, p. 30) further discovered that the use of public sector comparators to estimate VfM and to justify private sector involvement was not practised in the Bank-supported PPPs examined in its evaluation. At a global roundtable gathering on VfM practices, it emerged that often a VfM calculation is applied to projects already earmarked for a PPP arrangement (World Bank, 2013b). The VfM calculation then tends to have little significance for the decision to introduce a PPP in practice despite the purported importance attached to it in policy rhetoric.

PPP evaluations and assessments are also biased in their treatment of PPPs' associated fiscal impact. In an attempt to attract investors, governments often offer guarantees and various forms of subsidies to PPP investors, thereby increasing the fiscal cost. ${ }^{x v}$ Yet, in the World Bank's evaluation study it emerged that the contingent liabilities for governments associated with PPPs were rarely fully quantified at project level (IEG, 2014, p. 139). The result is that decision making processes are more likely to support PPP rather than traditional public procurement. A further bias towards PPPs results from accounting practices that 
This is the accepted version of an article accepted for publication in Journal of Development Studies published online 27 March 2017 Taylor \& Francis: http://dx.doi.org/10.1080/00220388.2017.1303671

Accepted version downloaded from SOAS Research Online: https://eprints.soas.ac.uk/23702

treat PPP liabilities as 'off-budget'. According to a recent IMF Report, this 'common misperception about PPPs often results in a government bias in favor of PPPs over traditional procurement.' (Jin \& Rial, 2016, p.22)

Boardman \& Hellowell (2016) propose reasons for the persistence of a bias against public provision. They suggest (p. 2) that '[f]irms that deliver PPP services - including major banks, civil engineering firms and consultants - are often major contributors to political parties, and have significant lobbying power'. The ideological predisposition of policy makers in support of private sector interventions certainly has strong backing from private investors. The close relationship between finance and development policymakers outlined above is likely to be a factor in the emergence of a policy that supports the interests of investors.

\section{Issues Arising}

Private sector involvement in infrastructure has long raised concerns. Common criticisms have included, first, that private investors have little interest in infrastructure investments in poor countries (see also UNCTAD, 2015). This is evidenced by the reality that between 2003 and 2013, middle-income countries (MICs) accounted for 61 per cent of private investment in infrastructure in developing countries; 37 per cent reached lower middle-income countries and only two per cent went to LICs. Most of the growth in PPPs in the last decade has indeed been driven by Latin America and the Caribbean, followed by South Asia 
This is the accepted version of an article accepted for publication in Journal of Development Studies published online 27 March 2017 Taylor \& Francis: http://dx.doi.org/10.1080/00220388.2017.1303671

Accepted version downloaded from SOAS Research Online: https://eprints.soas.ac.uk/23702

(Romero, 2015); and in 2014, five countries - Brazil, Colombia, India, Peru and Turkey - accounted for 73 per cent of private investment in infrastructure in developing countries (Hart et al., 2015). The allocation of private investment across sectors has also been uneven (see Figure 2). Information and communication technology (ICT) and electricity have accounted for over 70 per cent of total private investment (across the sectors identified in Figure 2) since 1990, while just three per cent of investment over the last twenty-five years has gone to water and sewerage. It seems hence unlikely that the private sector will alleviate the needs of poor households in poor countries in terms of access to basic services, despite the claims made by PPP supporters.

Figure 2: Private investment across sectors 1990-2015

Source: World Bank PPI database

Second, it has been repeatedly argued in the literature that rather than creating fiscal space (World Bank, 2013a), the financing costs of PPPs may exceed any other mode of financing public infrastructure (Griffiths et al. 2014). For the IMF (2015, p. 30), PPPs are 'generally considered to carry higher fiscal risks than budget financing' (see also Boardman et al., 2016). Private financing costs are typically higher, as governments can borrow more cheaply than the private sector (Engel et al., 2010, p. 17; Hall, 2014; National Audit Office, 2013). PPPs also involve large deal and consultancy fees. Engel et al. (2010, p. 17) cite evidence that costs incurred for legal, technical and financial advice can reach 10 
This is the accepted version of an article accepted for publication in Journal of Development Studies published online 27 March 2017 Taylor \& Francis: http://dx.doi.org/10.1080/00220388.2017.1303671

Accepted version downloaded from SOAS Research Online: https://eprints.soas.ac.uk/23702

per cent of the total cost of the project. Costs can escalate as a result of contract renegotiations, the incidence of which has been high (see Guasch et al., 2014, p. 22). And, costs are increased by government guarantees and various forms of subsidies to PPP investors ('contingent liabilities') (see Bova et al., 2016).

Rather than leveraging resources to plug the financing gap, in reality, PPPs then tie governments into long-term contracts, which absorb government finances. Funke et al. (2013, p. 9) insist that if a government 'cannot afford to finance the project using traditional public finance, it probably cannot afford to undertake it as a PPP. Conversely, if the government can afford to undertake the project as a PPP, it can probably also afford to finance it traditionally'. PPP liabilities have alarmed civil society campaigners who see these as a significant threat to the financial sustainability of poor countries (see Jones, 2015 for Global Justice Now and Romero, 2015 for Eurodad).

Third, it has previously been highlighted that increasing the involvement of the private sector in infrastructure provision in developing countries, necessitates need strong institutions to attract investors, to implement PPPs and to regulate the private sector. Evidence suggests that countries with high public investment attract strong private investment while countries with low public investment attract little private investment (Calderón \& Servén, 2010; World Bank, 2008). Thus, while strong state capacity and public investment are key prerequisites for a successful PPP programme, their presence may obviate the need for PPPs. 
This is the accepted version of an article accepted for publication in Journal of Development Studies published online 27 March 2017 Taylor \& Francis: http://dx.doi.org/10.1080/00220388.2017.1303671

Accepted version downloaded from SOAS Research Online: https://eprints.soas.ac.uk/23702

While PPPs raise private finance for infrastructure, their ability to do so critically depends on the policies and the creditworthiness of the public sector. xvi

Much of the empirical literature points to the need for strong state capacity to implement PPPs (Hart et al., 2015 p. 16; Schmidt-Traub \& Sachs, 2015; Trebilcock \& Rosentock, 2015). Compared with public procurement, PPPs place significant demands on the state at all stages, from pre-project preparation, to contract negotiation and management, and complexities multiply along with scale of projects (Romero, 2015; IEG, 2014). Weak capacity is not easily overcome by establishing laws and institutions. While many countries have established PPP units to negotiate with investors, institutional weaknesses often come to the fore when contracts are disputed. Even in the UK, with its high skills base and years of PPP experience, the National Audit Office (2011, paragraph 14) questions the ability of the state to negotiate and manage contracts as a result of the lack of its commercial skills as compared to those of the private sector. Further, the IEG (2014, p. v) finds that upstream donor support that seeks to address weak state capacity in the context of PPPs, 'failed in almost half of the cases because of the complexity and political implications of the reform processes'.

Yet, apart from these general and well-established critiques of promoting private sector involvement in the delivery of public services, the current financeoriented revival raises a set of additional issues, particularly in the context of development policy. Indeed, the PPP advocacy revival has changed the 
This is the accepted version of an article accepted for publication in Journal of Development Studies published online 27 March 2017 Taylor \& Francis: http://dx.doi.org/10.1080/00220388.2017.1303671

Accepted version downloaded from SOAS Research Online: https://eprints.soas.ac.uk/23702

understanding of infrastructure so that sector policy becomes guided by efforts to attract resources from the international financial sector.

First, with the availability of trillions of institutional finance as one of the core drivers of the current policy, infrastructure investment becomes assessed in terms of its 'bankability'. This implies that the needs of investors are prioritised over social outcomes when the provision of public service is reorganised to accommodate the imperative to generate competitive returns for private investors (O’Neill, 2013; Hebb \& Sharma, 2014). This often translates into fees or tariffs that condition access. Critical accountants have highlighted how across sectors and countries PPPs can act as a conduit for the redistribution of wealth away from taxpayers to financial and corporate sectors (see Shaoul et al., 2012, p. 38). Yet by focusing on such ambiguous concepts as VfM assessments and couching PPP advocacy in terms of risk and efficiency, the issue of financial interests and distribution remains largely obfuscated.

Similarly, Fine \& Hall (2012, p. 58) observe how the public good becomes 'subordinate to the imperative of designing a commercially viable contract'. Infrastructure's non-commercial outcomes or purposes become marginalised, with access regulated by capacity to pay and multiple purposes that could otherwise be attached to infrastructure reduced to guaranteeing profitability for investors. Furthermore, the reliance on private investment in infrastructure (and the need to generate revenue streams) may dictate the location and design of the projects to attract private investment, where the public sector loses the capacity 
This is the accepted version of an article accepted for publication in Journal of Development Studies published online 27 March 2017 Taylor \& Francis: http://dx.doi.org/10.1080/00220388.2017.1303671

Accepted version downloaded from SOAS Research Online: https://eprints.soas.ac.uk/23702

to cross-subsidise infrastructure investments that present less attractive commercial features (see also Hebb \& Sharma, 2014). For O’Neill (2010) the new understanding of infrastructure in terms of a portfolio of public, public-private and private provision arrangements, designed for specific purposes, targeted at selected groups and available often under commercial arrangements displaces the traditional approach to infrastructure which involved the systematic assessment of its social, economic and environmental consequences.

Second, the transformation of infrastructure into an asset class that is traded internationally produces tendencies towards standardisation in PPP processes, including those bearing on contracts and regulatory environment, to suit investors' needs rather than that contractual or regulatory arrangements reflect local specificities. It is telling, for example, that the UNECE proposal for a PPP standard for healthcare policy has no specific features drawing on the health sector as opposed to for instance power or transport.xvii The specific sector becomes incidental to the broader purpose of generating revenue streams for financial investors. Similar considerations are reflected in Arezki et al. (2016, p. 37) which denounces the lack of standardization of underlying infrastructure projects [as] an important impediment to the scaling up of investment into infrastructure-based assets'. The authors recommend the use of securitization techniques such as collateralized bond obligations or collaterised loan obligations to overcome the complexity and variegated nature of specific large infrastructure projects, without any further reflection of both the systemic and distributional implications of such financial techniques. Recent initiatives like 
This is the accepted version of an article accepted for publication in Journal of Development Studies published online 27 March 2017 Taylor \& Francis: http://dx.doi.org/10.1080/00220388.2017.1303671

Accepted version downloaded from SOAS Research Online: https://eprints.soas.ac.uk/23702

UNECE's call for 'people first PPPs' (UNECE, 2016) are unlikely to address the fundamental bias entailed through the infrastructure-as-asset logic.

Third, the current focus on bringing global finance to meet developing country infrastructure raises additional regulatory challenges. Ashton et al. (2012) show how PPP assets are valuable to investors, not just for the expected rate of return their operational activities may generate but also for the opportunities they provide for financial engineering. Based on analysis of investments in the USA they demonstrate that sophisticated financing techniques used, for example, to restructure debt finance, interest and dividend flows, have led to significant additional returns for investors. Such financial mechanisms increase the information asymmetries between government and investor, and constantly evolving financial practices raise challenges for regulation in long-term fixed contracts. In addition, in developing countries, fiscal resources risk being depleted by corporate activities. Research by Global Financial Integrity (2015) shows that of the $\$ 1$ trillion in illicit flows leaving poor nations annually, over 83 per cent is due to trade mis-invoicing where corporations under-value exports and over-value imports to appear to reduce corporate profits and associated tax liabilities (Kar and Spanjers, 2015). Bringing in more private finance with financial engineering practices into developing country infrastructure exposes governments, already known to be lacking in capacity, to greater risk of exploitation. 
This is the accepted version of an article accepted for publication in Journal of Development Studies published online 27 March 2017 Taylor \& Francis: http://dx.doi.org/10.1080/00220388.2017.1303671

Accepted version downloaded from SOAS Research Online: https://eprints.soas.ac.uk/23702

Finally, PPPs in general but particularly under financialised structures, can be expected to contribute to increased inequality both within and between countries. The packaging of infrastructure into bankable projects will direct spending to areas where returns are most secure and these may be hived off into pooled financial products leaving the state with the hardest (poorest) to serve. Despite the poverty reduction rhetoric of PPP policy referenced above, the World Bank finds that little is recorded on the poverty impact of PPPs and the extension of services to the poor is rarely an explicit objective of a PPP arrangement (IEG, 2014 p. 66; Trebilcock \& Rosenstock, 2015).

There is a dearth of assessments of the distributional impact of the deployment of PPPs to provide infrastructure in specific country settings. Such assessments need to go beyond an appraisal of specific contracts and examine broader implications both within a particular sector where a PPP arrangement is located and beyond. While PPPs may provide much-needed infrastructure to meet the needs of end users, this often comes at considerable cost. This needs to include considerations of a PPP's wider fiscal impact, illustrated by the case of a hospital PPP in Lesotho which consumed more than half of the country's national health budget (Webster, 2015). The fiscal cost and distributional implications of PPPs are accentuated when compared with state borrowing. The discrepancy in yield generated by a sovereign bond, for instance, as compared to a PPP infrastructure security, and hence the differential cost to the taxpayer or user of the facility, will have distributional implications. Further, through a PPP, institutional investors in such 'assets', often in the form of investment funds operating on behalf of the 
This is the accepted version of an article accepted for publication in Journal of Development Studies published online 27 March 2017 Taylor \& Francis: http://dx.doi.org/10.1080/00220388.2017.1303671

Accepted version downloaded from SOAS Research Online: https://eprints.soas.ac.uk/23702

world's richest, become connected with the world's poorest households, via their consumption of essential services (see Bayliss, 2013 for a discussion on water). User fees at one end of the financial chain are transformed into dividends at the other end of the chain.

\section{Conclusion}

This paper has argued that we have seen a recent revival in policy support for privatisation, in particular through a focus on PPPs. It has, further, asserted that while the current revival builds on previous privatisation initiatives, it also represents a departure due to the central role played by global finance. This has led to a shift in infrastructure policy which is increasingly focused on reconstructing public service provision around the needs of investors. Developing countries, rather than designing comprehensive public service provision plans, instead have lists of PPP pipeline projects that are up for sale internationally.

Yet, there is extensive evidence of the limits of PPPs in practice and this is particularly significant for poorer countries. These tend to have weak capacity for implementation and regulation together with low levels of public investment. Investors have little interest in such locations and PPPs create significant fiscal demands with little evidence of greater efficiency.

This paper has then sought to unpack the dynamics of the PPP revival and has 
This is the accepted version of an article accepted for publication in Journal of Development Studies published online 27 March 2017 Taylor \& Francis: http://dx.doi.org/10.1080/00220388.2017.1303671

Accepted version downloaded from SOAS Research Online: https://eprints.soas.ac.uk/23702

unveiled a remarkable disconnect between the promotion and realities of PPPs.

This disconnect is riddled with contradictions. Far from freeing resources to invest in poverty reduction, PPPs can absorb funds that could have been devoted directly to infrastructure investment. Rather than compensating for weak state capacity they place significant extra demands on it. Rather than substituting for public investment, investors are attracted to locations with high levels of public investment. PPPs draw on the resources of multilateral development institutions and governments which are deployed to create a context ('investment climate') and project profiles that are commercially attractive to private investors. Official agencies further provide funds to co-finance projects in order to reduce the risk exposure of private investors. And even if these efforts are successful and bids are attracted and contracts are signed, government agencies face the challenge of regulating and financing contracts with sophisticated private agents for decades into the future.

These contradictions call into question the merits of promoting PPPs to overcome developing countries' public service financing gap. The PPP revival fails to address long-standing drawbacks associated with privatisation and, instead, accentuates its challenges by reconstituting infrastructure as a financial asset. It seems unlikely that PPPs will contribute towards poverty reduction in low-income countries. Rather there is a risk that PPPs, when they materialise, may absorb limited public funds for decades into the future, thereby reducing fiscal space for pro-poor interventions. 
This is the accepted version of an article accepted for publication in Journal of Development Studies published online 27 March 2017 Taylor \& Francis: http://dx.doi.org/10.1080/00220388.2017.1303671

Accepted version downloaded from SOAS Research Online: https://eprints.soas.ac.uk/23702

Finally, in closing, we wish to highlight that macroeconomic trajectories,

including those bearing on financing infrastructure, embody specific conceptions of the role of the state, which are themselves outcomes of ongoing political and economic struggles within and across national boundaries. However, while fiscal consolidation has been promoted in the developing world by various organisations for over three decades, this has now come together with specific reconfigurations around infrastructure, in which new actors and processes acquire greater significance worldwide. As a result, the policies on how infrastructure should be financed, delivered and managed are changing with possibly deep-ranging implications across infrastructure's location, access and use. Previous notions of public good, positive externality and universal access are being displaced by considerations of financial viability of infrastructure as asset (O’Neill, 2010). Yet, there are alternatives. Ortiz et al. (2015), for example, show that even the poorest countries have been able to adopt diverse measures that sought to increase their fiscal space for social protection including by raising taxes and eliminating illicit financial flows. The challenges raised by PPPs outlined above indicate that greater attention is needed to broadening policy options for the much-needed upscaling of public service provision in developing countries. 
This is the accepted version of an article accepted for publication in Journal of Development Studies published online 27 March 2017 Taylor \& Francis: http://dx.doi.org/10.1080/00220388.2017.1303671

Accepted version downloaded from SOAS Research Online: https://eprints.soas.ac.uk/23702

\begin{abstract}
i Throughout this paper, we adopt a broad definition of infrastructure to include both what is, on the one hand, sometimes referred to as economic (or 'hard'), such as roads, ports, airports, etc. and, on the other, social (or 'soft') infrastructure such as education and health provision. As a result, infrastructure and public services are used interchangeably, with 'public' capturing the reality that the state retains some degree of (or all) responsibility for the service provision, regardless of varying levels of private sector involvement.

ii See Romero (2015) for at least 25 different types of PPP (see also IOB, 2013).

iii A World Bank Report described the privatisation policy prescription as 'oversold and misunderstood' (Kessides, 2004, p. 86)

iv This chart is derived from the World Bank Private Participation in Infrastructure Database which lists private investor commitments for water and sanitation, energy, transport and information and communications technology.
\end{abstract}

v See http://www.worldbank.org/mdgs/post2015.html for an overview of specific instruments through which blending of (multilateral) development finance can proceed. See also Table 1 of United Nations (2014) and WEF (2015).

${ }^{\text {vi }}$ Much of the recent discourse on leveraging tends to conflate donor assistance and private finance into a single resource for financing development, ignoring the starkly differing long-term cost implications attached to each financing source. See e.g. the Development Assistance Committee (DAC)'s introduction of a new measure of Official Development Assistance (ODA) called Total Official Support for Sustainable Development to capture 'finance made available thanks to the official sector' (OECD, 2014b).

vii http://www.afdb.org/en/topics-and-sectors/sectors/private-sector/areas-of-focus/publicprivate-partnerships/

viii http://www.afdb.org/en/topics-and-sectors/initiatives-partnerships/africa50/about-us/

ix The PPP Knowledge Lab provides an overview of all existing country PPP units across the world, see

https://pppknowledgelab.org/search?keys=PPP\%20unit\&restrict_pages=1\&site_source\%5B\%5 $\mathrm{D}=$ Handshake\%20Journal\&site_source\%5B\%5D=Knowledge\%20Lab

${ }^{x}$ See also quote from the AsDB above.

xi See also World Bank (2011, p. 5); WEF (2015); Schmidt-Traub and\& Sachs (2015); UNCTAD (2014).

xii http://www.worldbank.org/en/programs/global-Infrastructure-facility

xiii http://www.mckinsey.com/industries/infrastructure/our-insights/making-the-most-of-awealth-of-infrastructure-finance.

xiv http://www.worldbank.org/en/programs/global-Infrastructure-facility\#2

$\mathrm{xv}$ See Bayliss and Van Waeyenberge (2015) for a detailed discussion.

xvi In India, for instance, the India Infrastructure Finance Company Limited (IIFCL) was created as a non-banking finance company owned by the government with the aim of providing longterm debt to PPP projects. IIFCL raises funds from domestic and overseas markets under sovereign guarantees. These funds then provide long-term debt to PPP Special Purpose Vehicles. See https://blogs.worldbank.org/ppps/innovative-financing-case-india-infrastructure-financecompany.

xvii See

https://www2.unece.org/wiki/download/attachments/23758291/UNECE\%20healthcare\%20P PP\%20standard\%20-\%20Public\%20Review\%20-\%20v1.0.pdf 
This is the accepted version of an article accepted for publication in Journal of Development Studies published online 27 March 2017 Taylor \& Francis: http://dx.doi.org/10.1080/00220388.2017.1303671

Accepted version downloaded from SOAS Research Online: https://eprints.soas.ac.uk/23702

\section{References}

Alexander, N. (2015). The World Bank in the vanguard of an infrastructure boom. Bretton Woods Project Observer. Retrieved from http://www.brettonwoodsproject.org/2015/02/world-bank-infrastructure/ Alexandersson, G., \& Hulten, S. (2009). Prospects and pitfalls of public-private partnerships in railway transportation: Theoretical issues and empirical experience. International Journal of Transport Economics, 36, 97-119.

Arezki, R., Bolton, P., Peters, S., Samama F., \& Stiglitz J. (2016) From global savings glut to financing infrastructure: The advent of investment platforms. IMF Working Paper WP/16/18. Washington, DC: IMF.

AsDB. (2012). Public-Private Partnership operational plan 2012-2020. Asian Development Bank, Manila. Retrieved from http://www.adb.org/sites/default/files/institutional-document/33671/pppoperational-plan-2012-2020.pdf

Ashton, P., Doussard, M., \& Weber, R. (2012). The financial engineering of infrastructure: What are public assets worth to private investors? Journal of American Planning Association, 78, 300-12.

Bayliss, K. (2013). The financialisation of water. Review of Radical Political Economy. 46(3), 292-307.

Bayliss, K., \& Fine, B. (Eds.). (2008). Privatization and Alternative Public Sector Reform in Sub-Saharan Africa. London: Palgrave MacMillan.

Bayliss, K., \& Van Waeyenberge, E. (2015). Funding infrastructure: Critical observations and lessons for Cuba. Report prepared for conference El Papel de la 
This is the accepted version of an article accepted for publication in Journal of Development Studies published online 27 March 2017 Taylor \& Francis: http://dx.doi.org/10.1080/00220388.2017.1303671

Accepted version downloaded from SOAS Research Online: https://eprints.soas.ac.uk/23702

Inversión Extranjera en el Desarrollo de la Infraestructura Física en Cuba,

Organised by Centro de Estudios de la Economía Cubana and Institute of the Americas, University College London.

Boardman A., Siemiatycki M., \& Vining A. (2016). The theory and evidence concerning public-private partnerships in Canada and elsewhere. The School of Public Policy Research Papers, University of Calgary.

Boardman, A., \& Hellowell, M. (2016). A comparative analysis and evaluation of specialist PPP units: Methodologies for conducting value for money appraisals. Journal of Comparative Policy Analysis: Research and Practice 1-17.

Bova, E., Ruiz-Arranz, M., Tascani, F., \& Ture, E. (2016). The fiscal costs of contingent liabilities: A new dataset. IMF Working Paper. Washington, DC: IMF. Calderón, C., \&. Servén, L. (2010). Infrastructure in Latin America. World Bank Policy Research Working Paper 5317. Washington, DC: World Bank.

Çelik, S., \& Isaksson, M. (2013). Institutional investors as owners: Who are they and what do they do? OECD Corporate Governance Working Papers 11. Paris: OECD.

DAWM (2015). Why invest in infrastructure? Research Report by Deutsche Asset and Wealth Management. Retrieved from http://infrastructure.deutscheam.com/content/_media/Research_Deutsche_AW M_Why_Invest_in_Infrastructure_May_2015.pdf

Dutz, M., Harris, C., Dhingra, I.. \& Shugart, C. (2006). Public-private partnership units: What are they, and what do they do? The World Bank Group. Financial and Private Sector Development Vice Presidency Note number 311. 
This is the accepted version of an article accepted for publication in Journal of Development Studies published online 27 March 2017 Taylor \& Francis: http://dx.doi.org/10.1080/00220388.2017.1303671

Accepted version downloaded from SOAS Research Online: https://eprints.soas.ac.uk/23702

Engel, E., Fischer, R., \& Galetovic, A. (2010). The economics of infrastructure

finance: Public-private partnerships versus private provision. Documentos de Trabajo No 276. Centro de Economia Aplicada. Universidad de Chile.

EPEC. (2014). Establishing and reforming PPP units: Analysis of EPEC Member PPP Units and lessons learnt, European PPP Expertise Centre. Retrieved from: http://www.eib.org/epec/resources/publications/epec_establishing_and_refor ming_ppp_units_en1

Eurodad. (2013). A dangerous blend? The EU's agenda to 'blend' public development finance with private finance. Report for European Network on Debt and Development. Retrieved from http://eurodad.org/files/pdf/527b70ce2ab2d.pdf.

Ferrer, J., \& Behrens, A. (2011). Innovative approaches to EU blending mechanisms for development finance. CEPS Special Report. Bonn: BMZ.

Fine, B. (2008). Privatisation's Shaky Theoretical Foundations. In K. Bayliss \& B. Fine (Eds.) Privatization and Alternative Public Sector Reform in Sub-Saharan Africa (pp. 13-30). London: Palgrave MacMillan

Fine, B., \& Hall, D. (2012). Terrains of neoliberalism: Constraints and opportunities for alternative models of service delivery. In D. McDonald and G. Ruiters, (Eds.), Alternatives to Privatization: Public Options for Essential Services in the Global South (pp. 45-70). London: Routledge.

Funke, K., Irwin, T., \& Rial, I. (2013). Budgeting and reporting for public-private partnerships. International Transport Forum Discussion Paper 2013/07. Joint OECD/ITF Transport Research Centre, Paris. 
This is the accepted version of an article accepted for publication in Journal of Development Studies published online 27 March 2017 Taylor \& Francis: http://dx.doi.org/10.1080/00220388.2017.1303671

Accepted version downloaded from SOAS Research Online: https://eprints.soas.ac.uk/23702

Griffiths, J. (2012). 'Leveraging' private sector finance: How does it work and what are the risks? Report for BrettonWoodsProject. London.

Griffiths, J., Martin, M., Pereira, J., \& Strawson, T. (2014). Financing for

Development Post-2015 Improving the Contribution of Private Finance. European

Parliament, and Directorate-General for External Policies of the Union.

Luxembourg: Publications Office.

Guasch, J., Benitez, D., Portabales, I. \& Flor, L. (2014). Renegotiation of PPP

contracts: An overview of its recent evolution in Latin America. Discussion Paper

No. 2014-18, International Transport Forum. Paris: OECD.

Hall, D. (2014). Why public-private partnerships don't work: The many advantages of the public alternative. PSIRU Research Report. London: University of Greenwich.

Hamilton, G. (2009). Impact of the financial crisis on PPPs. Presentation at Conference Knowledge Sharing on Infrastructure Public-Private Partnerships in Asia, Seoul, Korea, 19-21 May 2009.

Hart, T., Krause, P., \& Miller, M. (2015). Bricks and dollars: Improving public investment in infrastructure. Report. London: Overseas Development Institute: London

Hebb, T., \& Sharma, R. (2014). New finance for America's cities. Regional Studies, $48,485-500$.

Heller, P. (2005). Understanding fiscal space. IMF Discussion Paper PDP/05/4. Washington, DC: IMF. 
This is the accepted version of an article accepted for publication in Journal of Development Studies published online 27 March 2017 Taylor \& Francis: http://dx.doi.org/10.1080/00220388.2017.1303671

Accepted version downloaded from SOAS Research Online: https://eprints.soas.ac.uk/23702

Hildyard, N. (2012). More than bricks and mortar - Infrastructure as an asset class. Report for The Corner House. Retrieved from

http://www.thecornerhouse.org.uk/resource/more-bricks-and-mortar.

IEG. (2014). World Bank Group support to public private partnerships: Lessons from experience in client countries, FY02-12. World Bank Independent Evaluation Group. Washington, DC: World Bank.

IMF. (2004). Public-private partnerships. Report prepared by the Fiscal Affairs Department. Washington, DC: IMF.

IMF. (2015). Making public investment more efficient. Staff Report. Washington, DC: IMF.

Inderst, G., \& Stewart, F. (2014). Institutional investment in infrastructure in developing countries: Introduction to potential models. World Bank Policy Research Working Paper 6780. Washington, DC: World Bank.

IOB. (2013). Public-private partnerships in developing countries. Government of the Netherlands, Ministry of Foreign Affairs.

Jin, H., \& Rial, I. (2016). Regulating local government financing vehicles and Public-Private Partnerships in China. IMF Working Paper WP/16/187.

Washington, DC: IMF.

Jones. T. (2015). The new debt trap: How the response to the last global financial crisis has laid the ground for the next. Report for Jubilee Debt Campaign. Retrieved from http://jubileedebt.org.uk/wp-content/uploads/2015/07/Thenew-debt-trap_07.15.pdf 
This is the accepted version of an article accepted for publication in Journal of Development Studies published online 27 March 2017 Taylor \& Francis: http://dx.doi.org/10.1080/00220388.2017.1303671

Accepted version downloaded from SOAS Research Online: https://eprints.soas.ac.uk/23702

Jupe, R. (2009). New Labour, public-private partnerships and rail transport policy. Economic Affairs, 29, 20-25.

Kar, D., \& Spanjers, J. (2015). Illicit financial flows from developing countries: 2004-2013. Report for Global Financial Integrity, Washington DC

Kessides, I. (2004). Reforming infrastructure: Privatisation, regulation and competition. World Bank, IBRD, Washington DC.

Martin, M. (2015). Private and blended development cooperation: Assessing their effectiveness and impact for achieving the SDGs. 2016 Development Cooperation Forum Policy Briefs, 7.

McKinsey. (2016). Bridging global infrastructure gaps. McKinsey Global Institute.

Miyamoto, K., \& Chifalo, E. (2015). Official development finance for infrastructure: Support by multilateral and bilateral development partners. OECD Development Co-operation Working Paper 25, Organisation for Economic Cooperation and Development, Paris.

Languille, S. (2016) Public-Private Partnerships in Education and Health (Africa, Asia and Latin America): A Literature Review, mimeo.

O’Neill, P. (2010) Infrastructure financing and operation in the contemporary city. Geographical Research, 48. 3-12.

O'Neill, P. (2013). The financialisation of infrastructure: The role of categorisation and property relations. Cambridge Journal of Regions, Economy and Society, 6, 441-54.

OECD. (2010). Dedicated public-private partnership units: A survey of institutional and governance structures. Paris: OECD. Retrieved from: 
This is the accepted version of an article accepted for publication in Journal of Development Studies published online 27 March 2017 Taylor \& Francis: http://dx.doi.org/10.1080/00220388.2017.1303671

Accepted version downloaded from SOAS Research Online: https://eprints.soas.ac.uk/23702

http://www.keepeek.com/Digital-Asset-

Management/oecd/governance/dedicated-public-private-partnership-

units 9789264064843-en\#.V5Hnv4596-o\#page1

OECD. (2014a). Private financing and government support to promote long-term investments in infrastructure. Paris: OECD.

OECD. (2014b). Development co-operation report 2014: Mobilising resources for sustainable development. Development co-operation report. Paris: OECD.

OECD. (2015). Official development finance for infrastructure. OECD Report to G20 finance ministers and central bank governors IIWG meeting in Berlin and G20 Finance Ministers and Central Bank Governors. Paris: OECD.

Ortiz, I., Cummins, M., \& Karunaethy, K. (2015) Fiscal Space for Social Protection: Options to Expand Social Investments in 187 Countries. ESS Working Paper No. 48, International Labour Office, Geneva.

Perkins, S. (2013). Better regulation of public-private partnerships for transport infrastructure: Summary and conclusions. Discussion Paper 06, Joint OECD/ITF Research Centre, Paris: OECD.

Roehrich, J., Lewis, M., \& George, G. (2014). Are public-private partnerships a healthy option? A systematic literature review. Social Science \& Medicine 113 (2014), pp. 110-119.

Romero, M-J (2015). What lies beneath? A critical assessment of PPPs and their impact on sustainable development. Report for European Network on Debt and Development, Brussels. 
This is the accepted version of an article accepted for publication in Journal of Development Studies published online 27 March 2017 Taylor \& Francis: http://dx.doi.org/10.1080/00220388.2017.1303671

Accepted version downloaded from SOAS Research Online: https://eprints.soas.ac.uk/23702

Schmidt-Traub, G. \& Sachs, J.D. (2015). Financing sustainable development:

implementing the SDGs through effective investment strategies and partnerships. Working Paper, Sustainable Development Solutions Networks.

New York. Retrieved from http://unsdsn.org/resources/publications/financing/

Shaoul, J., Stafford, A., \& Stapleton, P. (2012). The fantasy world of private finance for transport via public private partnerships. International Transport Forum. OECD, Paris.

Shirley, M., \& Walsh P. (2000). Public versus private ownership: The current state of the debate. World Bank Policy Research Working Paper 2420, IBRD, Washington DC.

Standard \& Poor's (2013). Out of the shadows: The rise of alternative financing in infrastructure. January 31 2013. Report by Standard and Poor's Ratings Services, London.

Standard \& Poor's (2014). Global infrastructure: How to fill a $\$ 500$ billion hole. January 16 2014. Report by Standard and Poor's Ratings Services, London.

Torchia, M., Morner, M., \& Calabro, A. (2015). Public-private partnerships in the health care sector: A systematic review of the literature. Public Management Review 17(2): 236-261.

Torrance, M. (2009). The rise of a global infrastructure market through relational investing. Economic Geography, 85, 75-97.

Trebilcock, M., \& Rosenstock M. (2015). Infrastructure public-private partnerships in the developing world: Lessons from recent experience. The Journal of Development Studies, 51, 335-354. 
This is the accepted version of an article accepted for publication in Journal of Development Studies published online 27 March 2017 Taylor \& Francis: http://dx.doi.org/10.1080/00220388.2017.1303671

Accepted version downloaded from SOAS Research Online: https://eprints.soas.ac.uk/23702

Tsamboulas, D., Verma, A., \& Moraiti, P. (2013). Transport infrastructure provision and operations: Why should governments choose private-public partnerships? Research in Transportation Economics, 38, 122-127.

UKAN. (2015). Leveraging aid: A literature review on the additionality of using ODA to leverage private investments. UK Aid Network. Retrieved from http://www.ukan.org.uk/wordpress/wp-content/uploads/2015/03/UKANLeveraging-Aid-Literature-Review-03.15.pdf.

UNCTAD. (2014). Investing in the SDGs: An action plan. World Investment Report 2014. Geneva: United Nations Conference on Trade and Development.

UNCTAD. (2015). Trade and Development Report. Geneva: United Nations Conference on Trade and Development

UNDESA. (2016). Public-private partnerships and the 2030 agenda for sustainable development: Fit for purpose? DESA Working Paper No. 148, United Nations Department of Economic and Social Affairs.

UNECE. (2016). Promoting people first public-private partnerships (PPPs) for the UN SDGs. United Nations Economic Commission for Europe, Inter-agency Task Force on Financing for Development, Issue Brief Series.

United Nations. (2014). Report of the intergovernmental committee of experts on sustainable development financing. Retrieved from https://sustainabledevelopment.un.org/content/documents/4588FINAL\%20RE PORT\%20ICESDF.pdf.

Vining, A., \& Boardman, A. (2008). Public-private partnerships in Canada: Theory and evidence. Canadian Public Administration, 51, 9-44. 
This is the accepted version of an article accepted for publication in Journal of Development Studies published online 27 March 2017 Taylor \& Francis: http://dx.doi.org/10.1080/00220388.2017.1303671

Accepted version downloaded from SOAS Research Online: https://eprints.soas.ac.uk/23702

Webster, P. (2015). Lesotho’s controversial public-private partnership project.

The Lancet 386 (14) pp. 1929-1931

Weeks, J., \& McKinley, T. (2007). The macroeconomic implications of. MDG-based strategies in sub-Saharan Africa. International Poverty Centre Policy Research Brief No.4. Retrieved from

http://www.sarpn.org/documents/d0002836/IPC_PolicyResearchBrief4_Oct20 07.pdf

WEF. (2015). Strategic infrastructure: Mitigation of political and regulatory risk in infrastructure projects. Geneva: World Economic Forum.

World Bank. (2008). The Growth Report: Strategies for sustained growth and inclusive development. Commission on Growth and Development, Washington DC: World Bank.

World Bank. (1981). Accelerated development in Sub-Saharan Africa, Washington, DC: World Bank

World Bank. (2010). Global Monitoring Report 2010: The MDGs after the Crisis, Washington DC: World Bank.

World Bank. (2011). Infrastructure Strategy Update, FY12-15. Transformation through Infrastructure, Retrieved from http://siteresources.worldbank.org/INTINFRA/Resources/Transformationthro ughinfrastructure.pdf

World Bank. (2013a). Financing for development post-2015. Washington DC: World Bank. Retrieved from 
This is the accepted version of an article accepted for publication in Journal of Development Studies published online 27 March 2017 Taylor \& Francis: http://dx.doi.org/10.1080/00220388.2017.1303671

Accepted version downloaded from SOAS Research Online: https://eprints.soas.ac.uk/23702

https://www.worldbank.org/content/dam/Worldbank/document/Poverty $\% 20$

documents/WB-PREM\%20financing-for-development-pub-10-11-13web.pdf

World Bank. (2013b). Value-for-money analysis: Practices and challenges.

Report from World Bank Global Round Table, 28 May 2013, Washington DC:

World Bank.

World Bank. (2015). Private Sector - an Integral part of Climate Action Post-

Paris, World Bank Feature Story. Retrieved from

http://www.worldbank.org/en/news/feature/2015/12/30/private-sector-an-

integral-part-of-climate-action-post-paris

World Bank. (2016). 2015 Global PPI Update, Washington, DC: World Bank.

Retrieved from

https://ppi.worldbank.org/ /media/GIAWB/PPI/Documents/Global-

Notes/Global2015-PPI-Update.pdf

World Bank/IMF. (2015). From billions to trillions: Transforming development

finance. Post-2015 Financing for Development: Multilateral Development

Finance. Development Committee, Discussion Note, DC2015-002 (April).

Retrieved from

http://siteresources.worldbank.org/DEVCOMMINT/Documentation/23659446/

DC2015-0002\%28E\%29FinancingforDevelopment.pdf. 